\title{
Norma dan Nilai dalam Ilmu Ekonomi Islam
}

\author{
Nurul Fahmi \\ Mahasiswa Pascasarjana Universitas Islam Negeri \\ Sunan Kalijaga Yogyakarta \\ dony_dol@yahoo.co.id
}

\begin{abstract}
Islam has been set up with the norms and values in each discipline of knowledge. Including Islamic economics, Islamic economics as a social science and theology is not only derived from the Qur'an and as-Sunnah, but also stems from empirical phenomena and economic problems in the field. Epistemologically, Islamic economics is divided into two disciplines: First, normative Islamic economics, which is the study of Islamic sharia laws relating to property affairs and treasures. Second, positive Islamic economics, which is the study of Islamic concepts relating to property affairs and treasures, especially with regard to the production of goods and services. Norms and values created in Islamic economics aims to provide moral and ethical order in the economy itself, because it is basically the purpose of Islamic economics in the world is reaching the livelihoods and happiness in the Hereafter (hayatun thoyyibah and falah both in this world and in the hereafter).
\end{abstract}

Keywords: Norms, values, Islamic economics 


\section{Pendahuluan}

Dewasa ini, kata "ekonomi Islam" selalu diidentikan dan dikaitkan dengan Lembaga Keuangan Syariah (LKS) seperti, perbankan syariah, Bait al Maal wat Tamwiil (BMT) atau koperasi syariah, pegadaian syariah (rahn), asuransi syariah (takaful), pasar syariah, mini market syariah, dan lain sebagainya. Hal ini dikarenakan sistem ekonomi yang berbasis syariah sedang booming, dan memiliki daya jual, marketable, yang cukup tinggi serta dapat menjanjikan pendapatan atau penghasilan (profitable) baik duniawi maupun ukhrowi. Artinya, jika seseorang menjalankan sistem ekonomi yang berbasisis syariah, hendaknya ia dapat memetik buah berupa keuntungan sebagai ma'isyah, yang ia niatkan semata-mata untuk menjalankan ibadah kepada Allah SWT. Sehingga ia mendapatkan dua profit sekaligus dalam satu proses aktivitas, dengan cara yang insyaallah halal dan thoyyib.

Gambaran aktivitas tersebut sesuai dengan kaedah fiqh yang berbunyi mā lā yatimmul wājib illā bihi fahuwa wājib, artinya "sesuatu yang harus ada untuk menyempurnakan yang wajib, maka ia wajib (harus) diadakan". Mencari ma'isyah atau nafkah (melakukan aktivitas ekonomi) ialah wajib. Oleh karena pada era modern ini, aktivitas perekonomian kurang dan bahkan tidak akan sempurna tanpa adanya LKS, maka LKS pun wajib diadakan. Dengan demikian, kaitan antara LKS dengan ekonomi Islam menjadi lebih gamblang (jelas) lagi. (Karim, 2007: 14-15).

Sebelum menjadi praktek-praktek ekonomi seperti yang dipaparkan di atas, tentunya melalui diskursus teori (teori ekonomi) di kalangan para ekonom dengan memperhatiakan realitas empiric aktivitas manusia pada umumnya. Jadi praksis ekonomi yang ada saat ini merupakan hasil dari suatu proses aplikasi teori ekonomi.

Dalam ilmu ekonomi konvensional, pemikir awal yang melahirkan istilah "ekonomi” yaitu Aristoteles yang merupakan seorang filosof mengemukakan: kata "ekonomi" berasal dari bahasa Yunani oikos nomos, oikos (keluarga atau rumah tangga), nomos (peraturan atau hukum). Sebelum lahirnya ilmu ekonomi, timbul gejala ekonomi yang merupakan bagian 
dari diskursus filsafat. Jadi pemikiran ekonomi konvensioanal seperti ekonomi kapitalis belum menjadi "teori ekonomi" (Spencer, 1977), tetapi saat itu dikenal dengan istilah "filsafat ekonomi". Contohnya karya Adam Smith (Bapak Ekonomi Konvensional) yang berjudul The Theory of Moral Sentiment paling tidak menjelaskan ilmu ekonomi sebagai moral sains serta terdapat pembahasan filosofis di dalamnya (Rahardjo, 2001: xiii).

Oleh karena itu, jika dikaitkan dengan ilmu ekonomi Islam yang sedang berkembang pada saat ini, lantas muncul pertanyaan. Apakah ekonomi Islam mempunyai landasan filosofis? Dan apakah terdapat nilai serta norma di dalam ekonomi Islam?

\section{Telaah Pusataka}

Menurut Jeremy Seabrook (Seabrook, 2006: 69) perkembangan ilmu ekonomi Islam erat kaitannya dengan tujuan landasan filosofisnya sendiri, tidak dapat dipungkiri bahwa ekonomi Islam mulai muncul setelah masa kejayaan (renaissance) sistem ekonomi kapitalis dan sosialis yang dianggap sedang mengalami fase degradasi karena ekonomi hanya dikendalikan oleh segelintir orang atau negara "berduit" sehingga hal ini berakibat pada bertambahnya angka kemiskinan dan merajalelanya pengangguran di berbagai Negara, oleh karenanya ekonomi Islam digadang-gadang menjadi sistem alternatif yang harapannya mampu memberikan solusi atas banyaknya permasalahan ekonomi dan mampu menciptakan kemaslahatan bagi masyarakat.

Dampak positif setelah masa kejayaan (renaissance) ekonomi Barat ialah banyaknya bermunculan wacana islamisasi ilmu pengetahuan (1970-an) oleh para cendikiawan muslim di berbagai belahan dunia sesuai dengan bidang keilmuannya masing-masing yang tujuannya mencegah mafsadat dan dehumanisasi, serta menjunjung tinggi rasa keadilan (al'adl). Salah satu disiplin ilmu pengetahuan yang saat itu sering diperbincangkan adalah islamisasi ilmu ekonomi menjadi ilmu ekonomi Islam. Karena disiplin ilmu ini tidak hanya membahas tentang ontologi, 
epistimologi, aksiologi, dan metodologinya saja akan tetapi banyak diaplikasikan dalam aktivitas kehidupan masyarakat sehari-hari. (Yusdani, 2007: 77).

\section{Pembahasan}

\section{Definisi Ekonomi Islam}

Pada hakikatnya, belum ada definisi yang baku mengenai ekonomi Islam. Beberapa definisi di bawah ini tidak terlepas dari profil, background pendidikan, keluarga, kondisi sosial, politik, dan ekonomi yang dialami oleh sang tokoh pada masa itu. Terlepas dari itu semua, semuanya tetap merujuk kepada al-Qur'an dan al-hadits sebgai sumber rujukan pertama dan utama. Guna pemahaman lebih mendalam, berikut ini akan dijabarkan beberapa definisi ekonomi dalam Islam menurut para ahli:

Menurut S.M. Hasanuzzaman, "ilmu ekonomi Islam adalah pengetahuan dan aplikasi ajaran-ajaran dan aturan-aturan syariah yang mencegah ketidakadilan dalam pencarian dan eksplorasi berbagai macam sumber daya, untuk memberikan kepuasan (satisfaction) lahir dan batin bagi manusia serta memungkinkan mereka melaksanakan seluruh kewajiban mereka terhadap Sang Kholiq dan masyarakat (Rahardjo, 1999: 10)." Sedangkan M.A. Mannan, "ilmu ekonomi Islam adalah suatu ilmu pengetahuan sosial yang mempelajari permasalahan ekonomi dari orangorang yang memiliki nilai-nilai Islam. (Mannan, 1993: 19)"

Lain halnya dengan Khursid Ahmad, menjelaskan "ilmu ekonomi Islam adalah suatu upaya sistematis untuk mencoba memahami permasalahan ekonomi dan perilaku manusia dalam hubungannya dengan permasalahan tersebut dari sudut pandang Islam (Chapra, 2001: 121)." Sedangkan M.N. Siddiqi, menuturkan "ilmu ekonomi Islam merupakan respon para pemikir muslim terhadap tantangan-tantangan ekonomi pada masa hidup mereka. Yang sumber utamanya al-Qur'an dan as-Sunnah maupun akal dan pengalaman (Chapra, 2001: 121)." M. Akram Khan, mendefinisikan "ilmu ekonomi Islam bertujuan mempelajari kesejahteraan manusia (falah) yang dicapai dengan mengorganisir 
sumber-sumber daya bumi atas dasar kerjasama dan partisipasi (Chapra, 2001: 121)."

Sementara Louis Cantori, "ilmu ekonomi Islam tidak lain merupakan upaya untuk merumuskan ilmu ekonomi yang berorientasi manusia dan berorientasi masyarakat yang menolak ekses individualisme dalam ilmu ekonomi klasik (Chapra, 2001: 121).” Munawar Iqbal, menggaris bahawi, "ekonomi Islam adalah sebuah disiplin ilmu yang menjadi cabang dari syariat Islam. Dalam perspektif Islam, wahyu dipandang sebagai sumber utama IPTEK (mamba'ul 'ilmi). Kemudian al-Qur'an dan al-hadits dijadikan sebagai sumber rujukan untuk menilai teori-teori baru berdasarkan doktrin-doktrin ekonomi Islam (Sudarsono, 2002: 12)."

Sesungguhnya masih banyak lagi definisi ekonomi Islam yang di paparkan oleh para pemikir yang konsen terhadap perkembangan ekonomi Islam, akan tetapi kiranya dari beberapa definisi di atas, seyogyanya dapat mewakili definisi-definisi ekonomi Islam yang sudah ada, sehingga dapat dikonklusikan bahwa menurut Islam ekonomi adalah ilmu yang mempelajari segala prilaku manusia dalam memenuhi kebutuhan hidupnya dengan tujuan memperoleh falah di dunia dan akhirat (hereafter) (P3EI, 2008: 2-3), yang mana diatur berdasarkan aturan agama Islam (syariat) dan dilandasi dengan tauhid sebagaimana dirangkum dalam rukun iman dan rukun Islam.

Islam (dalam Ekonomi) berfungsi sebagai identitas tanpa mempengaruhi makna atau pengertian ekonomi itu sendiri. Sebab pengertiannya lebih ditentukan oleh perspektif atau lebih tepat lagi worldview yang digunakan sebagai landasan nilai. Kemudian ekonomi dan bekerja merupakan aktivitas yang egaliter dan kolektif yang diwajibkan oleh Allah SWT, sebagaimana termaktub dalam QS. At-Taubah ayat 105: "Dan katakanlah, bekerjalah kamu, karena Allah dan Rasul-Nya serta orang-orang yang beriman akan melihat pekerjaan itu". Kerja juga mengharapkan maghfiroh, sebagaimana sabda Rasulullah: "Barang siapa diwaktu sorenya kelelahan karena kerja tangannya, maka diwaktu sore itu ia mendapat ampunan (maghfiroh).” (Hadits Riwayat Thabrani dan Baihaqi) 


\section{Epistimologi Ekonomi Islam}

Epistimologi merupakan bagian dari teori tentang pengetahuan (theory of knowledge). Teori adalah pengetahuan ilmiah yang mencakup penjelasan mengenai suatu faktor tertentu dari sebuah disiplin ilmu. Teori biasanya muncul setelah ada proses pemikiran yang panjang (filsafat) kemudian diuji (verifikasi) sehingga timbulah sebuah teori. Proses filsafat mencari tahu itu menghasilkan kesadaran, yang disebut pengetahuan (knowledge). Adapun Teori ekonomi Islam bersumber dari al-Qur'an dan al-hadits. Sedangkan filsafat ekonomi Islam bersumber dari Agama (ad-diin). Pemikiran tentang ekonomi Islam bermula dari respons para cendikiawan muslim terhadap tantangan dan permasalahan ekonomi pada masa mereka. Pemikiran ekonomi Islam tersebut diilhami dan dilandaskan dari ajaran al-Quran dan sunnah, yang kemudian dilanjutkan dengan proses ijtihad dari pengalaman empiris atau realitas sosial yang terjadi.

Secara terminologi, epistimologi adalah cabang ilmu filsafat yang mengecek tentang keotentikan pengertian, metode struktur, dan faliditas pengetahuan. Secara garis besar epistimologi dapat dikatakan sebagai ilmu yang mempelajari tentang substansi yang bersangkutan dengan pengetahuan (knowledge), oleh karena itu epistimologi berkaitan dengan beberapa hal di bawah ini:

a. Filsafat, yaitu sebagai cabang yang mencari keabsahan dan kebenaran pengetahuan.

b. Metode, memiliki maksud mengantarkan manusia mencapai tujuan (goal).

c. Sistem, bertujuan memperoleh realitas atau hakikat kebenaran pengetahuan (knowledge).

Untuk lebih memahami bagaimana proses menurunkan ilmu ekonomi Islam dan mengetahui kesetaraan dari kedudukan metode observasi, induksi, dan deduksi mari kita perhatikan gambar alur epistimologi ekonomi Islam berikut ini (Suseno, 2009: 10). 
Gambar 3.1

Epistimologi Ekonomi Islam

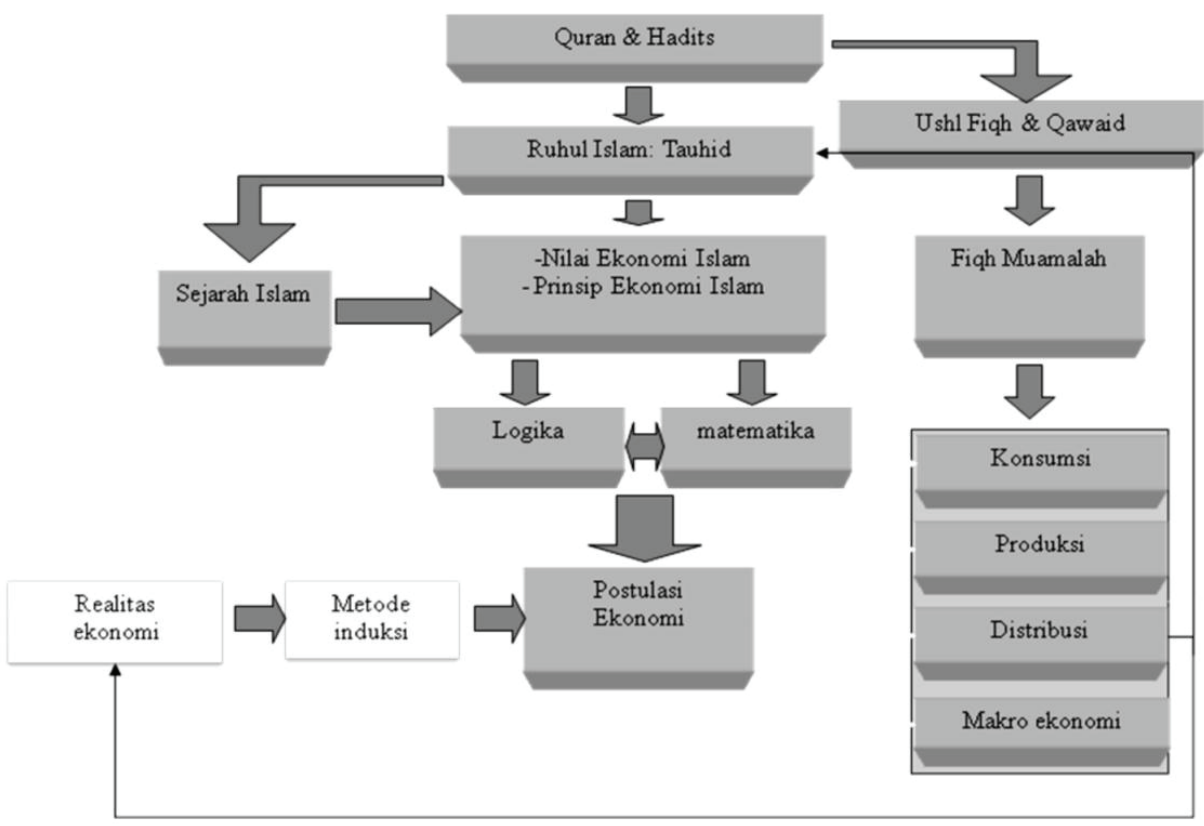

Teori ekonomi Islam dibangun dari realitas empirik dan masalah faktual, sehingga hubungan teori ekonomi Islam dengan teori lain dan hubungan teori ekonomi Islam dengan praktek saling berkaitan. Eksistensi ekonomi Islam bukan berlandaskan perspektif manusia sebagai human of economic semata, tetapi berdasarkan perspektif manusia sebagai hamba Allah yang dilahirkan di dunia secara fitrah (suci), dan didasarkan juga kepada 4 (empat) aksioma yaitu; equilibrium (keseimbangan), free will (kebebsan berkehendak), unity (kesatuan), dan responbility (pertanggung jawaban) (Alwi, 2010: 2).

Oleh sebab itu, metodologi ekonomi Islam digunakan untuk mengungkap dan mengklarifikasi permasalahan ekonomi yang multidimensial. Tindakan ini digunakan untuk menjaga obyektifitas dalam proses pengungkapan kebenaran terhadap suatu fenomena. Secara alami unsur manusiawi atau kemanusian akan menguji bahwa segala fenomena ber- 
ujung pada keselarasan (equilibrium) yang selalu berkelanjutan. Hal ini yang kemudian melahirkan sikap dinamis dan progesif, yaitu rasa syukur yang muncul karena keberhasilan atau kegagalan dari sebuah proses usaha untuk mencari atau menemukan kebenaran.

Sedangkan kebenaran ilmiah dapat diuji dan ditemukan melalui beberapa hal berikut ini: Koheren, merupakan suatu pernyataan yang dianggap benar apabila konsisten dan memiliki koherensi dengan pernyataan yang sebelumnya yang dianggap benar. Teori koheren ini menggunakan logika deduktif.

Pertama, Koresponden, yaitu pernyataan yang dianggap benar apabila materi pengetahuan yang terkandung dalamnya berhubungan atau memiliki korespondensi dengan obyek yang dituju oleh pernyataan tersebut. Teori ini menggunakan logika induktif. Kedua, Pragmatis, suatu yang dianggap benar apabila memiliki kegunaan atau manfaat yang bersifat fungsional dalam kehidupan sehari-hari. Oleh karenanya epistimologi ini berasal dari tiga metode yaitu:

1) Observasi. Merupakan upaya untuk melihat, mengamati dan mengevaluasi fakta dan realita yang ada, kemudian membuat asumsi, klasifikasi, abstraksi, hakikat, tipe ideal dengan menggunakan generalisasi. Observasi merupakan proses yang harus dilakukan untuk menggali dan mendapatkan informasi mengenai suatu obyek. Observasi diperlukan untuk menjadi suatu bukti atas realitas fenomena yang berhubungan dengan aktivitas manusia. Dengan observasi manusia bisa melakukan efisiensi aktivitas dan bisa melakukan forcasting atas suatu yang akan terjadi.

2) Deduksi. Penalaran deduktif membahas cara-cara atau metode untuk mendapatkan kesimpulan yang falid dengan terlebih dahulu diajukan pertanyaan-pertanyaan.

3) Induksi. Induksi membahas tentang pengambilan kesimpulan dari pernyataan-pernyataan secara spesifik atas fenomena-fenomena yang ada. Pernyataan tersebut hanya bersifat probabilitas dan hipotesa dari pernyataan-pernyataan yang telah diajukan. 
Dalam ekonomi Islam selain dari fenomena dan realitas sosial, hubungan informasi dapat dihasilkan dari al-Qur'an dan alhadits (http://ekiszone.com).

\section{Nilai-Nilai dalam Ekonomi Islam}

Nilai dasar ekonomi Islam adalah seperangkat nilai yang telah diyakini dengan segenap keimanan, dimana ia akan menjadi landasan paradigma ekonomi Islam. Nilai nilai dasar tersebut berdasarkan alQuran dan as-Sunnah. Kemudian sebagai ekonomi yang bersifat Rabbani maka Ekonomi Islam mempunyai sumber "nilai-nilai normatifimperatif" (meminjam istilah dari Ismail Al Faruqi), sebagai panduan serta pedoman yang mengikat. Dengan mengakses kepada aturan Ilahiyah (ketuhanan), setiap perbuatan manusia mempunyai unsur moral, etika, dan ibadah. Setiap tindakan manusia tidak boleh lepas dari nilai, yang secara vertical merefleksikan moralitas yang baik, dan secara horizontal memberi manfaat bagi manusia dan makhluk lainnya. Nilai moral samahah (lapang dada, lebar tangan dan murah hati) ditegaskan sebagai prasyarat bagi pelaku ekonomi untuk mendapatkan rahmat atau kasih dari Tuhan, baik selaku pedagang/pebisnis, produsen, konsumen, debitor maupun kreditor.

Prinsip atau nilai sebagai landasan dan dasar pengembangan ekonomi Islam terdiri dari 5 (lima) nilai universal, yaitu: tauhid (keimanan), 'adl (keadilan), nubuwwah (kenabian), khilafah (pemerintahan), dan ma'ad (hasil). Kelima nilai ini menjadi dasar inspirasi untuk menyusun proposisi-proposisi dan teori-teori ekonomi Islam. Rincian dari nilainilai universal ekonomi Islam tersebut dapat dijelaskan serta dipaparkan sebagai berikut (Muhammad dan Karim, 1999: 22):

\section{a. Tauhid (Keesaan Tuhan).}

Tauhid merupakan fondasi fundamental ajaran Islam. Tauhid itu yang membentuk 3 (tiga) asas pokok filsafat Ekonomi Islam, yaitu: Pertama, "dunia dengan segala isinya adalah milik Allah Swt dan berjalan menurut kehendak-Nya" (QS. Al-Ma'idah: 20, QS. Al-Baqarah: 6). 
Manusia sebagai khalifah-Nya hanya mempunyai hak kepemimpinan (khilafat) dan pengelolaan yang tidak mutlak/ absolut, serta harus tunduk melaksanakan hukum-Nya.

Akibatnya apabila kita menggunakan mafhum mukhalafah, dapat dikatakan bahwa mereka yang menganggap kepemilikan secara mutlak/ tak terbatas berarti telah ingkar kepada hukum Allah SWT. Implikasi dari status kepemilikan menurut Islam adalah hak manusia atas barang atau jasa itu terbatas. Hal ini jelas berbeda dengan kepemilikan mutlak oleh individu pada sistem kapitalis dan oleh kaum proletar pada sistem sosialis. Kedua, "Allah SWT adalah pencipta semua makhluk dan semua makhluk tunduk kepada-Nya" (QS. Al-An'am: 142-145, QS. An-Nahl: 10-16, QS. Faathir: 27-29, QS. Az-Zumar: 21). Dalam perspektif Islam, kehidupan di dunia hanya dipandang sebagai ujian dan sementara (tidak kekal/abadi), dimana akan diberikan kenikmatan dengan surga yang abadi bagi mereka yang dikasihi-Nya, sebagai sesuatu yang sifatnya non materil, yang tidak dapat dijadikan patokan dan tidak dapat diukur dengan sesuatu yang pasti (absolut), dan ini sulit untuk dimasukkan ke dalam analisis ekonomi konvensional.

Sedangkan ketidakmerataan karunia atau nikmat dan kekayaan yang diberikan Allah kepada setiap makhluk-Nya merupakan kuasa dan kehendak Allah semata. Dengan tujuan agar mereka yang diberi kelebihan nikmat bisa selalu bersyukur kepada Sang pemberi rizki dengan cara menyisihkan dan memberikan sebagian hartanya kepada orang-orang yang berhak menerimanya (delapan ashnaf). Sehingga akan tumbuh aktivitas ekonomi yang merata secara egaliter. Ketiga, secara horizontal iman kepada Hari Akhir (kiamat) akan mempengaruhi perilaku manusia dalam aktivitas ekonomi. Misalnya seorang muslim yang ingin melakukan aktivitas ekonomi tertentu, maka ia juga akan mempertimbangkan akibat setelahnya (akibat jangka panjang). Hal ini bermaksud agar setiap individu muslim dalam memilih aktivitas ekonomi tidak hanya memikirkan kenikmatan sesaat kala itu saja (jangka pendek) akan tetapi ia selalu berfikir akibat baik dan buruknya jauh ke depan. Karena kehidupan di dunia hanya "numpang lewat" untuk mencari bekal kelak di akhirat. 


\section{b. 'Adl (Keadilan).}

Allah adalah Sang pencipta seluruh yang ada di muka bumi ini, dan 'adl (keadilan) merupakan salah satu sifat-Nya. Allah menganggap semua manusia itu sama (egalitarianism) di hadapan-Nya dan memiliki potensi yang sama untuk berbuat baik, karena yang menjadi pembeda bagi-Nya hanya tingkat ketaqwaan setiap individunya. Implikasi prinsip 'adl (keadilan) dalam ekonomi Islam ialah: pemenuhan kebutuhan pokok bagi setiap masyarakat, sumber pendapatan yg terhormat, distribusi pendapatan dan kekayaan secara merata, dan pertumbuhan dan stabilitas ekonomi yang baik. (Karim, 2003: 8-9).

Hal ini tersirat dalam QS. Al-An'am: 152 yang intinya bahwa Allah memerintah kepada manusia agar dapat berlaku adil dalam segala hal, terutama kepada mereka yang sedang diamanahi kekuasaan dan mereka yang senantiasa berhubungan dengan transaksional bermu'amalah atau berniaga (Nuruddin, 1994: 233).

\section{c. Nubuwwah (Kenabian).}

Karena sifat cinta, kasih, sayang, dan kebijaksanaan Allah, manusia tidak dibiarkan semena-mena hidup di dunia ini tanpa mendapat petunjuk dan bimbingan dari-Nya. Maka dari itu diutuslah para nabi dan rasul sebagai delegasi dalam menyampaikan petunjuk Allah kepada manusia tentang bagaimana hidup yang baik, benar, dan berkah (hayatun thoyyibah) di dunia, dan mengajarkan jalan/cara untuk kembali kepada Allah jika ia melakukan kesalahan atau kekhilafan (taubah).

Salah satu tugas rasul adalah menjadi model terbaik yang harus diteladani manusia agar mendapatkan keselamatan (salamah) di dunia dan akhirat. Karena hal ini selaras dengan sabda Rasul yang artinya "Sesungguhnya aku diutus untuk menyempurnakan akhlak yang mulia". (termaktub dalam Shahih Bukhari). Kemudian ditegaskan oleh Allah SWT dalam QS. Al-Qalam: 4 melalui firman-Nya yang berarti: "Dan sesungguhnya kamu (Muhammad) benar-benar berbudi pekerti yang agung", dan dalam QS. Al-Ahzab: 21 yang artinya "Sesungguhnya telah 
ada pada (diri) Rasulullah itu suri teladan yang baik bagimu (yaitu) bagi orang yang mengharap (rahmat) Allah dan (kedatangan) hari kiamat dan dia banyak menyebut Allah".

Dari satu hadist dan dua ayat di atas dapat disarikan, bahwa Nabi Muhammad merupakan model yang ideal dalam segala perilaku, termasuk juga di dalamnya perilaku ekonomi dan bisnis yang seyogyanya dapat diteladani serta diimplementasikan oleh setiap manusia, khususnya para pelaku ekonomi dan bisnis. Nabi Muhammad juga merupakan nabi terakhir dan nabi penyempurna dalam ajaran Islam, sehingga tidak heran jika ia memiliki 4 (empat) sifat yang sering dijadikan landasan dalam aktivitas manusia sehari-hari termasuk juga dalam aktivitas ekonomi dan bisnis karena selain bidang leadership ia juga sangat perpengalaman dalam bidang perdagangan, berikut penjelasan implementasi 4 (empat) sifat Nabi dalam aktivitas ekonomi dan bisnis (al-Diwany, 2003: 161):

Pertama, Siddiq (benar, jujur, valid). Idealnya sifat ini dapat menjadi visi hidup setiap manusia. Dari sifat siddiq ini akan muncul konsep turunan, yaitu efektivitas dan efisiensi. Efektivitas dimaksudkan untuk mencapai tujuan yang tepat (on time) dan benar (all right), sedangkan efisiensi adalah melakukan aktivitas dengan benar dan hemat, maksudnya menggunakan teknik dan metode yang tidak menyebabkan kemubadziran; Kedua, Amanah (responsibility, dapat dipercaya, kredibilitas).

Apabila sifat ini diimplementasikan dalam praktek maka akan membentuk pribadi yang kredibel dan memiliki sikap penuh tanggung jawab. Kolektifitas dari setiap individu dengan kredibilitas dan tanggung jawab yang tinggi dapat menciptakan masyarakat yang kuat. Sifat amanah memiliki posisi yang fundamental dalam aktivitas ekonomi dan bisnis, karena tanpa kredibilitas dan tanggung jawab dalam berperilaku, maka kehidupan ekonomi dan bisnis akan amburadul (tidak stabil).

Ketiga, Fathanah (kecerdasan, kebijaksanaan, profesionalitas, intelektualitas). Sifat ini dapat dijadikan strategi dalam hidup, karena untuk mencapai ma’rifatullah (mengenal Allah melalui ayat-ayat dan tanda- 
tanda kebesaran-Nya), setiap individu harus mengoptimalkan segala potensi yang telah diberikan oleh-Nya. Potensi paling bernilai yang menjadi pembeda manusia dengan makhluk lain dan hanya dianugrahkan pada manusia adalah al-'aqlu (intelektualita). Implikasi sifat ini dalam aktivitas ekonomi dan bisnis adalah bahwa segala aktivitas ekonomi harus dilakukan dengan ilmu atau kecerdasan, dan optimalisasi semua potensi akal (al-'aqlu) yang ada untuk mencapai tujuan (goal).

Memiliki kredibilitas dan responsibility yang tinggi saja belum cukup dalam menjalankan kehidupan berekonomi dan berbisnis. Tetapi apabila dilengkapi dengan akal cerdas dan sikap profesionalitas yang mumpuni maka hal ini akan lebih mudah dalam menjalankannya (konsep "work hard and smart"). Keempat, Tabligh (komunikatif, transparansi, marketeble). Merupakan soft skill yang selayaknya dimiliki oleh setiap manusia, karena setiap pribadi beragama mengemban tanggung jawab penyampaian (da'wah). Sifat tabligh dalam ekonomi dan bisnis menurunkan prinsip-prinsip ilmu komunikasi (personal, interpersonal), seperti penjualan, pemasaran, periklanan, pembentukan opini masa, dan lain sebagainya.

\section{d. Khilafah (Pemerintahan).}

Khilafah merupakan representasi bahwa manusia adalah pemimpin (khalifah) di dunia ini dengan dianugerahi seperangkat potensi mental dan spiritual oleh Allah SWT, serta disediakan kelengkapan sumberdaya alam atau materi yang dapat dimanfaatkan dalam rangka untuk sustainibilitas atau keberlangsungan hidupnya. Sehingga kosep khilāfah ini melandasi prinsip kehidupan kolektif manusia atau hablum minannas dalam Islam. Fungsi utamanya adalah untuk menjaga keteraturan interaksi (mu'amalah) antar pelaku ekonomi dan bisnis, agar dapat meminimalisir kekacauan, persengketaan, dan keributan dalam aktivitas mereka. (http://ekonomisyariah.blog.gunadarma.ac.id).

Implikasi dari prinsip khilāfah dalam aktivitas ekonomi dan bisnis adalah: persaudaraan universal, kepercayaan bahwa sumber daya adalah amanah, kewajiban agar berpola hidup hemat dan sederhana, dan 
setiap individu memiliki kebebasan yang dapat dipertanggungjawabkan dan kebebasan tersebut dibatasi dengan kebebasan antar sesama manusia sebagai wujud dari hablum minannas. Semua itu dalam rangka untuk mencapai tujuan syariah (maqāshid as-syariah), yang mana maqāshid as-syariah dalam perspektif Al-Ghazali adalah untuk menciptakan kemaslahatan dan kesejahteraan manusia. Hal ini dicapai dengan menjaga atau melindungi agama (hifzu ad-din), jiwa (hifzu annafs), akal (hifzu al-'aql), keturunan (hifzu an-nasl), dan harta manusia (hifzu al-māl).

\section{e. Ma'ad (Hasil).}

Pada dasarnya manusia diciptakan di dunia ini untuk berjuang, dari belum bias berjalan menjadi bisa berlari, dari belum bisa melafalkan kata-kata menjadi bisa berbicara, dan masih banyak contoh lainnya. Dalam perspektif Islam dunia adalah ladang akhirat, maksudnya dunia merupakan tempat bagi manusia untuk mencari bekal dengan bekerja, beraktivitas, dan beramal shaleh. Kelak amalnya itu akan mendatangkan kebahagiaan dan mendapatkan balasan, baik semasa hidup di dunia maupun ketika di akhirat nanti. Pada prinsipnya perbuatan baik akan dibalas dengan kebaikan, dan demikian juga sebaliknya. Oleh karena itu, ma’ād bermakna balasan, imbalan, ganjaran. Menurut Imam AlGazhali implikasi konsep ma'ād dalam kehidupan ekonomi dan bisnis misalnya, mendapatkan profit/laba sebagai motivasi para pelaku bisnis. Laba tersebut bisa didapatkan di dunia dan bisa juga kelak akan diterima di akhirat. Karena itu konsep profit/laba mendapatkan legitimasi dalam Islam (Karim, 2003: 11-12).

\section{Ekonomi Islam Sebagai suatu Ilmu dan Norma}

Dari paparan dan penjelasan di atas, secara epistemologis ekonomi Islam dapat dibagi menjadi 2 (dua) disiplin ilmu; Pertama, ekonomi Islam normatif, yaitu ilmu yang mempelajari tentang hukum-hukum syari’ah yang fokusnya pada urusan harta benda (al- māl). Cakupannya adalah: (1) kepemilikan (al-milkiyah), (2) pemanfaatan kepemilikan 
(tasharruf fi al-milkiyah), dan (3) distribusi kekayaan kepada masyarakat (tauzi'at al-tsarwah baina an-nās). Bagian ini merupakan pemikiran yang terikat nilai atau valuational, karena diperoleh dari sumber nilai Islam, melalui metode deduksi (istinbath) hukum syariah dari sumber hukum Islam yaitu al-Quran dan as-Sunnah.

Ekonomi Islam normatif ini oleh Syaikh Taqiyuddin an-Nabhani disebut sistem ekonomi Islam (an-nizhām al-iqtishādi fi al-Islām) (al-Jawi, 2005: 1-4). Kedua, ekonomi Islam positif, yaitu ilmu yang mempelajari tentang konsep-konsep Islam yang berkaitan dengan urusan harta benda, spesifiknya yang berkaitan dengan produksi barang dan jasa. Cakupannya adalah segala macam cara (uslub) dan sarana (wasilah) yang digunakan dalam proses produksi barang dan jasa. Bagian ini merupakan pemikiran universal, karena diperoleh dari pengalaman dan fakta empiris, melalui metode induksi terhadap fakta-fakta empiris parsial dan generalisasinya menjadi suatu kaidah atau konsep umum (al-Jawi, 2005: 1-4). Bagian ini tidak harus mempunyai dasar konsep dari al-Quran dan as-Sunnah, tapi cukup disyaratkan tidak boleh bertentangan dengan al-Quran dan as-Sunnah. Ekonomi Islam positif ini oleh Syaikh Taqiyuddin an-Nabhani disebut ilmu ekonomi Islam (al-'ilmu al-iqtishādi fi al-islām).

Ilmu Ekonomi Islam merupakan teori atau hukum-hukum dasar yang menjelaskan perilaku-perilaku antar variabel ekonomi dengan memasukkan unsur norma ataupun tata aturan tertentu (unsur Ilāhiyah). Oleh karena itu, Ekonomi Islam tidak hanya menjelaskan faktafakta secara riil, tetapi juga harus menerangkan idealitas yang seyogyanya dapat dilakukan, dan apa yang seharusnya terjadi dan dikesampingkan atau dihindari, idealita ini dilandasi atas dasar nilai (value) dan norma (norm) tertentu, baik secara eksplisit maupun implisit, kemudian inilah yang disebut dengan ekonomi normatif. Sedangkan ekonomi positif bahasannya lebih terfokus kepada realitas relasi ekonomi atau mengenai fenomena yang nyatanya terjadi (P3EI, 2008, 23-26).

Menurut Adiwarman Azhar Karim, dengan demikian, maka ekonom muslim, perlu mengembangkan suatu ilmu ekonomi yang khas, 
yang dilandasi oleh nilai-nilai Iman dan Islam yang tidak hanya dihayati tetapi juga diamalkannya, yaitu ilmu ekonomi Islam. Sebuah sistem ekonomi yang juga menjelaskan segala fenomena tentang perilaku pilihan dan pengambilan keputusan dalam setiap unit ekonomi dengan memasukkan tata aturan syari'ah sebagai variabel independent (ikut mempengaruhi segala pengambilan keputusan ekonomi), yang berasal dari Allah SWT. meliputi batasan-batasan dalam melakukan kegiatan ekonomi. Proses integrasi norma dan aturan syariah ke dalam ilmu ekonomi, disebabkan adanya pandangan bahwa kehidupan di dunia tidak dapat dipisahkan dengan kehidupan di akhirat. Semuanya harus seimbang karena dunia adalah sawah atau ladang akhirat. Keuntungan (return) yang kelak diperoleh seseorang di akhirat, bergantung pada apa yang ia telah investasikan di dunia (Karim, 2003: 6).

Lebih lanjut Chapra mengemukakan bahwa sesungguhnya sistem ekonomi Islam telah terbentuk dan berkembang secara berkala sebagai subyek interdisipliner sesuai dengan paradigma Islam. Hal ini dapat dilihat dari berbagai karya yang telah dihasilkan oleh para Fuqaha (ahli fiqih), Ulama dan Ekonom Muslim antara lain; (1) Malik (93-179 $\mathrm{H}$ ), pemikiran-pemikirannya adalah bahwa raja atau penguasa harus bertanggung jawab terhadap kesejahteraan rakyatnya dan konsep maslahah (nilai kegunaan barang baik untuk individu maupun sosial); (2) Muhammad bin Hasan Al-Shaibani (132-189 H), telah merumuskan konsep tentang pendapatan dan belanja rumah tangga, pentingnya sektor pertanian, dan kerjasama serta bagi hasil; (3) Yahya ibn Adam Al-Qarashi $(203 \mathrm{H})$, mengenalkan konsep keuangan publik/pajak; (4) Abu Yusuf (731-798 H), konsep tentang keuangan negara; (5) Ibn Miskawaih $(1030 \mathrm{H})$, konsep tentang pertukaran dan peranan uang; (6) Al-Ghazali (1055-1111 H) membahas tentang standar minimum kebutuhan hidup dan norma-norma kehidupan sosial; (7) Ibn Taimiyah (1263-1328 H) memberikan perhatian kepada masalah kemasyarakatan dan al-hisbah; (8) Ibn Khaldun (1332-1404 H), beberapa ide yang dikembangkannya adalah pembagian kerja, uang dan harga, produksi dan distribusi, perdagangan internasional, ekonomi publik, pertumbuhan ekonomi, kemiskinan dan kemakmuran. Para pemikir muslim telah 
mengidentifikasi banyak konsep, variabel, dan teori-teori ekonomi yang masih relevan hingga kini dan telah memberikan kontribusi yang sangat berarti bagi perkembangan ilmu ekonomi modern (Chapra, 2002: 7-32).

\section{Penutup}

Setiap ilmu atau pengetahuan tentu tidak bisa terlepas dari sebuah landasan atau dasar filosofis, begitu juga halnya dengan ekonomi Islam yang sedang menjadi trend saat ini. Ilmu (science) dalam perspektif Islam lebih diartikan sebagai segala pengetahuan yang terbukti kebenarannya secara ilmiah yang mampu mendekatkan manusia kepada Allah SWT, biasa disebut dengan kebenaran absolut. Sedangkan Ilmu (science) dikenal luas dalam dunia konvensional adalah segala ilmu yang memenuhi kaidah-kaidah metode ilmiah, biasa disebut dengan kebenaran relatif. Ilmu ekonomi Islam bukan cabang atau bukan berasal dari ilmu ekonomi konvensional atau sekuler. Tetapi, ilmu hasil ijtihad (inovasi dan kreasi) ulama yang dalam terminologi Islam tergolong dalam content fiqh mu'amalah.

Ilmu ekonomi Islam merupakan ilmu sosial sekaligus ilmu agama yang tentu saja tidak bebas dari norma dan nilai-nilai moral. Karena nilai moral merupakan aspek normatif yang integral dan harus dimasukkan dalam analisis fenomena ekonomi serta dalam teknik pengambilan keputusan yang berdasarkan syariah. Sehingga dapat menghasilkan konsep yang kompetibel dan universal serta menjunjung tinggi asas manfaat dan maslahah sebagai rahmatan lil ālamin.

Adapun sistem ekonomi Islam mempunyai karakteristik antara lain; sistem ekonomi berlandaskan etika, sistem ekonomi yang bercirikan kemanusiaan, dan ekonomi yang bersifat pertengahan (ummatan wasathon). Karakteristik sistem ini merupakan penjabaran dari ajaran Islam sendiri yang terdapat dalam kitab suci Al-Qur'an dan Sunnah Nabi. Sehingga dalam Islam, sikap kāffah (secara menyeluruh dalam melaksanakan ajarannya) sangatlah diutamakan, maka dalam semua aktivitas hidupnya seorang muslim haruslah selalu berpedoman pada al-Qur'an 
dan Sunnah Nabi. Tidak terkecuali pada aktivitas perekomian yang dijalaninya.

Ekonomi Islam mempunyai tujuan untuk memberikan keselarasan bagi kehidupan di dunia (likay lā yakuna daulatan baina al aghniyā). Norma dan nilai Islam bukan semata-semata hanya untuk kehidupan muslim saja, tetapi seluruh mahluk hidup di muka bumi. Esensi proses ekonomi Islam adalah pemenuhan kebutuhan manusia yang berlandaskan syariah agar mencapai kesejahtraan duniawi sekaligus kebahagian ukhrowi (falah).

\section{Daitar Pustaka}

A. A, Muhammad dan Adiwarman A. Karim. 1999. Sistem, Prinsip dan Tujuan Ekonomi Islam, alih bahasa Imam Saefuddin. Bandung: Pustaka Sejati.

A. Karim, Adiwarman. 2001. Sejarah Pemikiran Ekonomi Islam. Jakarta: International Institute of Islamic Thought Indonesia (IIIT). . 2003. Ekonomi Islam Suatu Kajian Kontemporer. Jakarta: Gema Insani Press.

Abdul, M.M. 1993. Teori dan Praktek Ekonomi Islam. alih bahasa M.Nastangin. Yogyakarta: Dana Bhakti Wakaf.

Al-Diwany, Thoriq. 2003. Bunga Bank dan Masalahnya; Suatu Tinjauan Syar'i dan Ekonomi Keuangan. Bandung: Akbar.

Chapra, M. Umer. 2001. Masa Depan Ekonomi Sebuah Tinjauan Islam. Jakarta: Gema Insani Press.

. 2002. "Perlukah Memiliki Sistem Ekonomi Islam?". Jurnal Muamalah. SEF FE UGM. Vol. 1. No. 1.

http://ekiszone.com http://ekonomisyariah.blog.gunadarma.ac.id

M. Shiddiq al-Jawi, "Paradigma Ekonomi Islam", paper pada hari Jum'at, 09 September 2005. 
Nuruddin, Amir. 1994. "Konsep Keadilan Dalam Al-Quran dan Implikasinya Pada Tanggung Jawab Moral”, Disertasi pada Program Pascasarjana IAIN Sunan Kalijaga. Yogyakarta.

Pusat Pengkajian dan Pengembangan Ekonomi Islam (P3EI). 2008. Ekonomi Islam. Jakarta: Rajagrafindo Persada.

Priyonggo Suseno. "Dasar-dasar dan Ruang Lingkup Ekonomi Islam". Paper disampaikan pada Workshop Nasional Pengajaran Ekonomi Islam untuk Perguruan Tinggi. Yogyakarta, 2009.

Rahardja, M. Dawam. 1999. Islam dan Transformasi Sosial Ekonomi. Jakarta: Lembaga Studi Agama dan Filsafat.

Seabrook, Jeremy. 2006. Kemiskinan Global: Kegagalan Model EkonomiNeoliberalisme. Yogyakarta: Resist Book.

Sudarsono, Heri. 2002. Konsep Ekonomi Islam suatu Pengantar. Yogyakarta: EKONISIA.

Syafaruddin Alwi. "Islamic Economic Thinking". makalah disampaikan pada Perkuliah Mata Kuliah Filsafat Ekonomi Islam. Yogyakarta, 29 Mei 2011.

Yusdani. 2007. "Islamisasi Model al-Faruqi dan Penerapannya dalam Ilmu Ekonomi Islam di Indonesia (Suatu Kritik Epistemik)", Jurnal Ekonomi Islam La Riba, Vol.1, No.1. 